Arch. histol. jap., Vol. 38, No. 5 (1976) p. $339-346$

Department of Oral Anatomy (Prof. T. OGAwA), Nippon Dental College, Niigata, and Sado Marine Biological Station (Dr. Y. HonMA), Faculty of Science, Niigata University Niigata, Japan

\title{
Light and Scanning Electron Microscopic Studies on the Esophageal Spines in the Pacific Ridley Turtle, Lepidochelys olivacea*
}

\author{
Sumio Yoshie and Yoshiharu Honma
}

Received September 4, 1975

\begin{abstract}
Summary. The peculiarly specialized esophagus of the Pacific ridley turtle, Lepidochelys olivacea, was described by light and scanning electron microscopic studies.

The esophagus is lined by a stratified squamous epithelium with remarkable keratinization, and its major part forms a number of large spines which have been called "pharyngeal teeth." The epithelium consists of three strata: stratum germinativum, stratum spinosum and stratum corneum. The surface of the spine is covered by a scaly keratin of possibly sloughing cells, and the cornified layer on the spine is very thick (more than $100 \mu$ ), reaching 3 to 7 times the depth of the corresponding layer in other parts.

This peculiar structure in the marine turtle without toothed jaws probably is used for breaking food into small pieces.
\end{abstract}

On the occasion of dissection of the Pacific ridley turtle to make histological preparation of some of the organs, it was noticed that the esophageal region of the specimen was equipped with a number of well developed processes (Honma and Yoshie, 1975). This tropical turtle, very rare in the Japanese Islands, was stranded after a heavy storm on a sandy beach of the western part of Niigata City on January 25, 1974. This is the third time on record that this species has been found in the Central Japan Sea.

In the case of the green turtle, Chelonia mydas, the structure similar to the present specimen was named as the pharyngeal papillae (Bellairs, 1969). However, no report dealing with histological documentation of these structures seems available. In order to know the structural detail and possible function of these esophageal papillae, histological observation was undertaken and a comparison of the related structures was made among several vertebrates without toothed jaws.

\section{Material and Methods}

The external and internal features of this female Pacific ridley turtle, Lepidochelys olivacea, have been described elsewhere to identify the species (Honma and Yoshie, 1975). After macroscopic observation was achieved, every small block of the lining epithelium was removed with one or two spines. For light microscopy, the block was immersed in 10\% formalin or Bouin's solution, embedded in wax following dehydration by methanol, and cut into 8 to $10 \mu$ thick sections mainly in a sagittal direction. Then, the sections were stained by various methods, such as Delafield's hematoxylin-eosin, azan trichrome, van Gieson, and periodic acid Schiff (PAS) reaction counter stained by light green and orange G.

*Contributions from the Sado Marine Biological Station, Niigata University, No. 250. 
For scanning electron microscopy, several pieces of spines immersed in $10 \%$ formalin were dehydrated by ethanol, and dried in the air. Next, the material was placed on spinner stubs and coated with gold in a vacuum evaporator, and was observed and photographed in a JSM-U3 type scanning electron microscope under the accelerating voltage of $25 \mathrm{kV}$.

\section{Results}

As shown in the picture, numerous, crowded papillae growing from the mucosal lining epithelium of the esophagus are projected into the lumen, and all their tips, better called prickles, are directed downward to the stomach (Fig. 1). The spine (=papilla) is a sharp, coniform shape tapering to a pointed tip, and is extremely hard and stout (Fig. 1, 2). However, the lining epithelium at the base of the spine is soft and somewhat flexible (Fig. 2). The size of the spine is variable, 2 to $10 \mathrm{~mm}$ in diameter
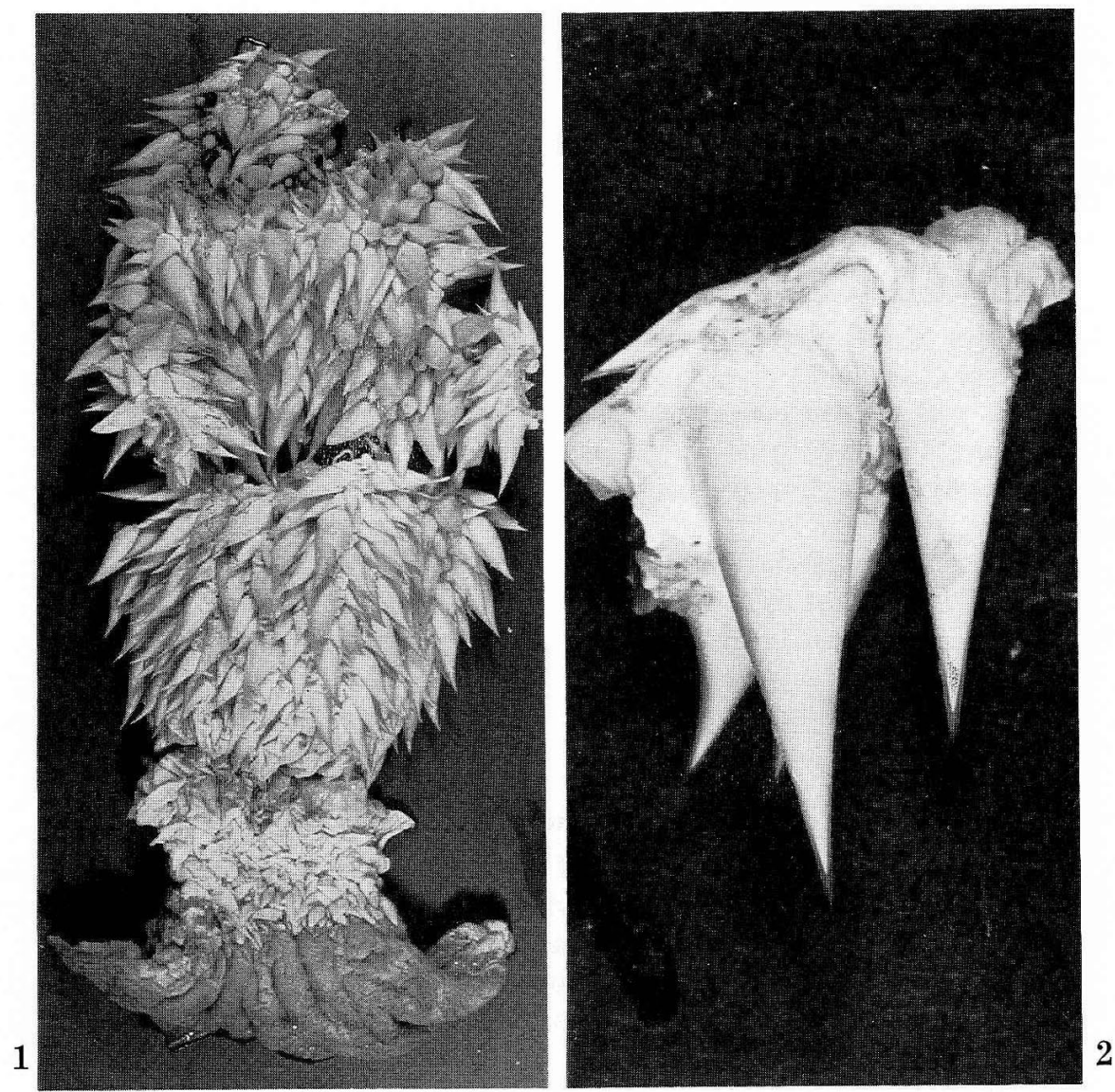

Fig. 1. General appearance of the esophagus-cardiac portion of the Pacific ridley turtle to show the highly specialized papillae (=spines) into the lumen. Notice most tips are directed downward to the stomach. $\times 0.42$

Fig. 2. Enlarged view of the spines. $\times 3$ 

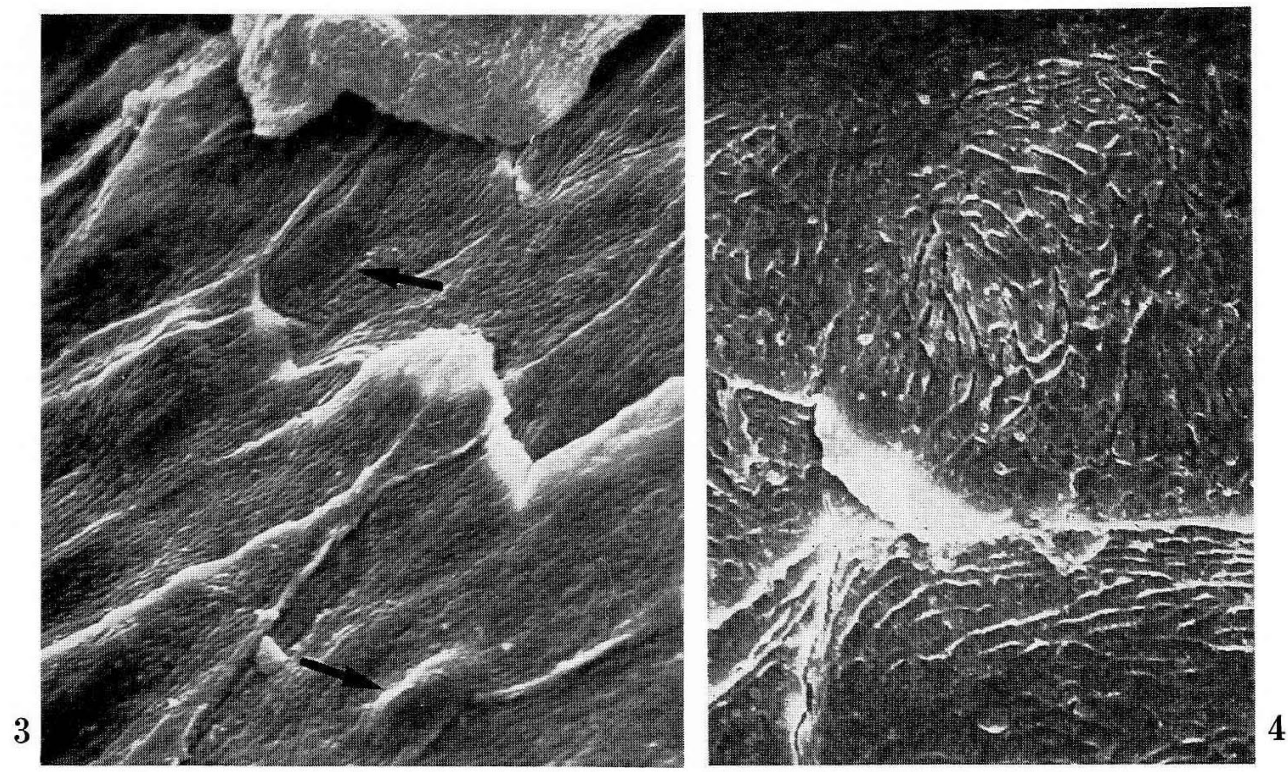

Fig. 3. A scanning electron micrograph of the surface squamous coat of the spine. Deeply keratinized feature and nuclear elevation (arrows) are recognized. $\times 1,400$

Fig. 4. Detail of the surface coat of the spine showing a number of fine folds. $\times 2,700$

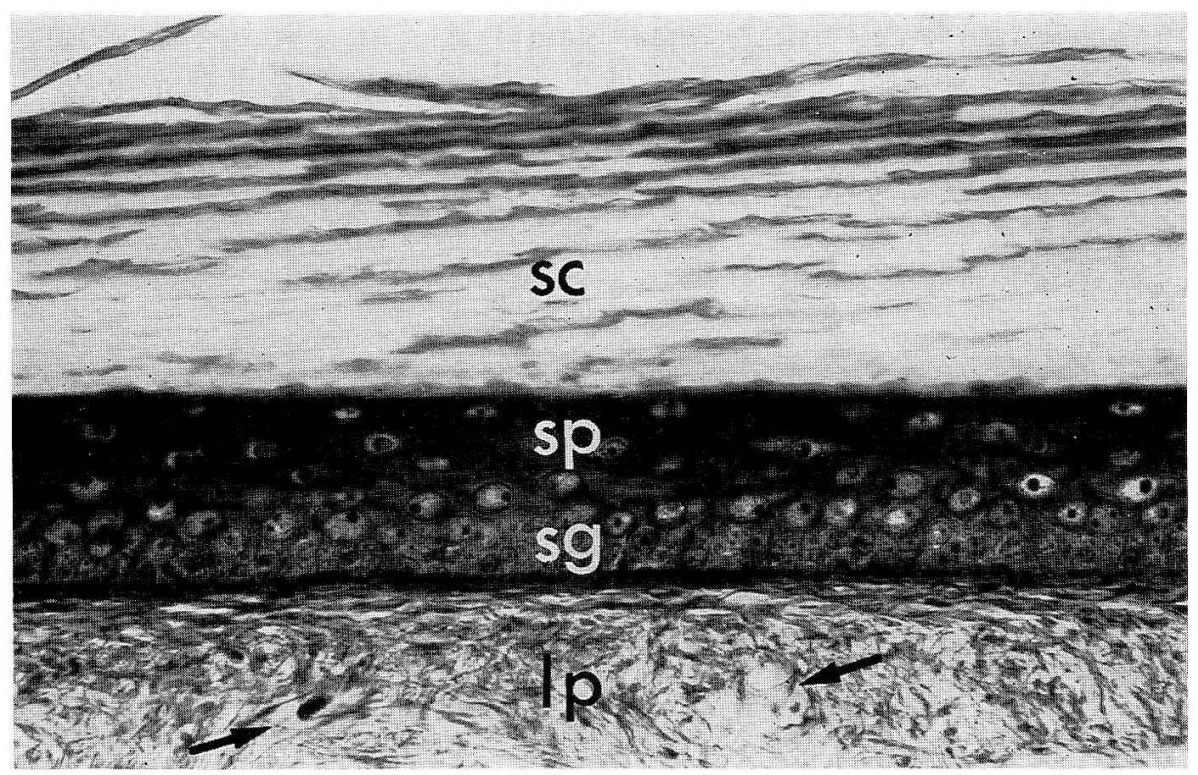

Fig. 5. A section of a part of spine in sagittal direction. Note that the highly keratinized cornified layer covering the spine is remarkably thick, and a prominent nucleolus is contained in the cell nucleus of the stratum spinosum. Ip lamina propria, $s g$ stratum germinativum, $s p$ stratum spinosum, $s c$ stratum corneum. Azan triple stain. $\times 260$ 
of the base and 6 to $25 \mathrm{~mm}$ in height. A group of spines in the central portion of the esophagus are the largest and best developed, while the distal one fourth of the mucosa near the stomach lacks these hard spines. Instead of spines, the portion adjacent to the cardia is covered with a soft projection with a dull tip (Fig. 1).

The surface of the spine is coated with scaly material of keratinized nature, when viewed by scanning electron microscopy (Fig. 3). A number of fine folds are occasionally seen in the scaly structure (Fig. 4). The protuberances derived from nuclear elevation are recognized here and there (Fig. 3).

Under the light microscope, the entire esophagus is lined by a keratinized, stratified squamous epithelium consisting of three major strata: stratum germinativum at
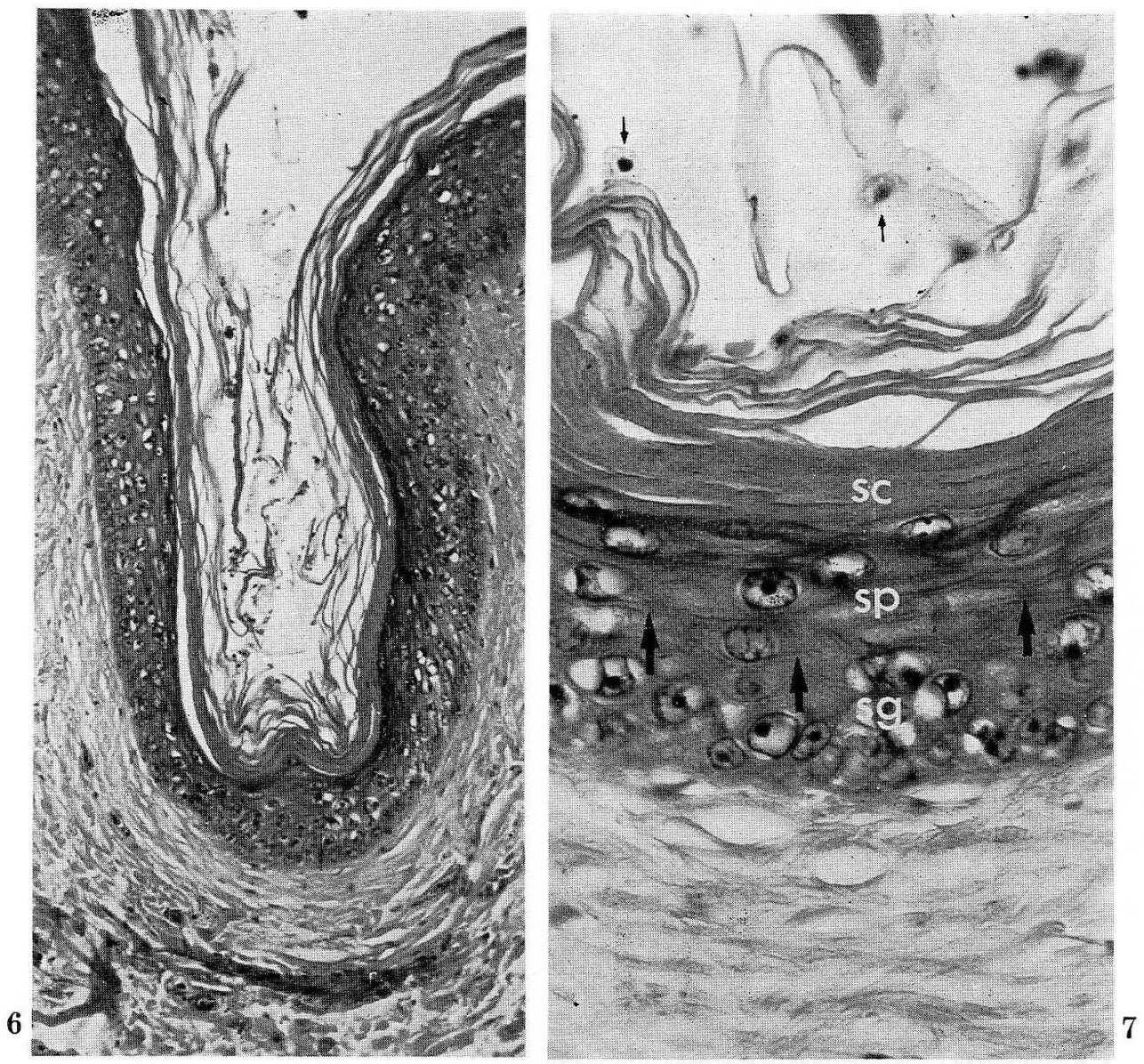

Fig. 6. A part of the mucosal epithelium in the anterior portion of the esophagus to show the sloughing cornified layer. Hematoxylin-eosin stain. $\times 130$

Fig. 7. Enlarged view of the three strata: stratum germinativum $(s g)$, stratum spinosum $(s p)$ and stratum corneum $(s c)$. Intercellular bridges (thick arrows) are recognized in the stratum spinosum. In this picture, several nuclear elements in the lumen (thin arrows) are noticed. Hema- 

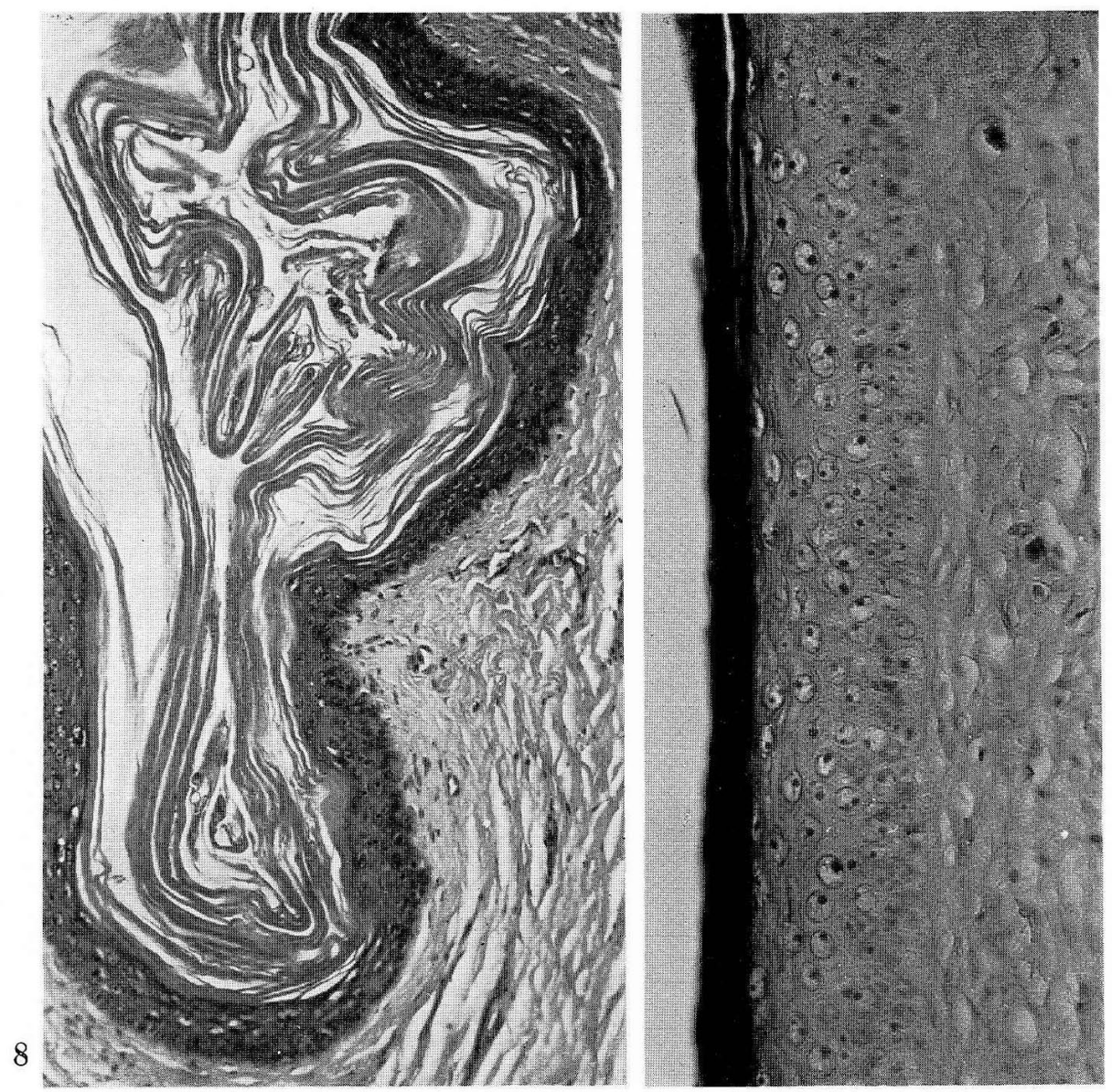

Fig. 8. A part of the mucosal epithelium in the central portion of the esophagus to show well developed sloughing cornified layer in regular stratification. Hematoxylin-eosin stain. $\times 130$

Fig. 9. The mucosal epithelium in the posterior portion of the esophagus equipped with dull tipped spines. The regular layers of the stratum corneum are stained intensely with acid dyes. Azan triple stain. $\times 260$

the bottm, stratum spinosum and stratum corneum (Fig. 5-10). The stratum germinativum is composed merely of a single layer of low columnar cells, the nucleus of which includes one or two prominent nucleoli (Fig. 7, 9). No sign of a mitotic figure is detected anywhere in this layer, however. Immediately above this layer, there are found the ovoid cells belonging to the stratum spinosum. The intercellular bridges are noticed in this spinous layer (Fig. 7). The nucleus of this type of cell contains a prominent nucleolus (Fig. 5). Upwards, these oval cells gradually change into elongate ones, and in the marginal region the cells are much more flattened with increasing acidophilia (Fig. 7, 9). The nuclei are now deprived of nucleoli in association with regressive change (Fig. 7). At any part the depth of the epithelium exclusive of the stratum corneum is fairly constant, measuring about $75 \mu$. The stratum 

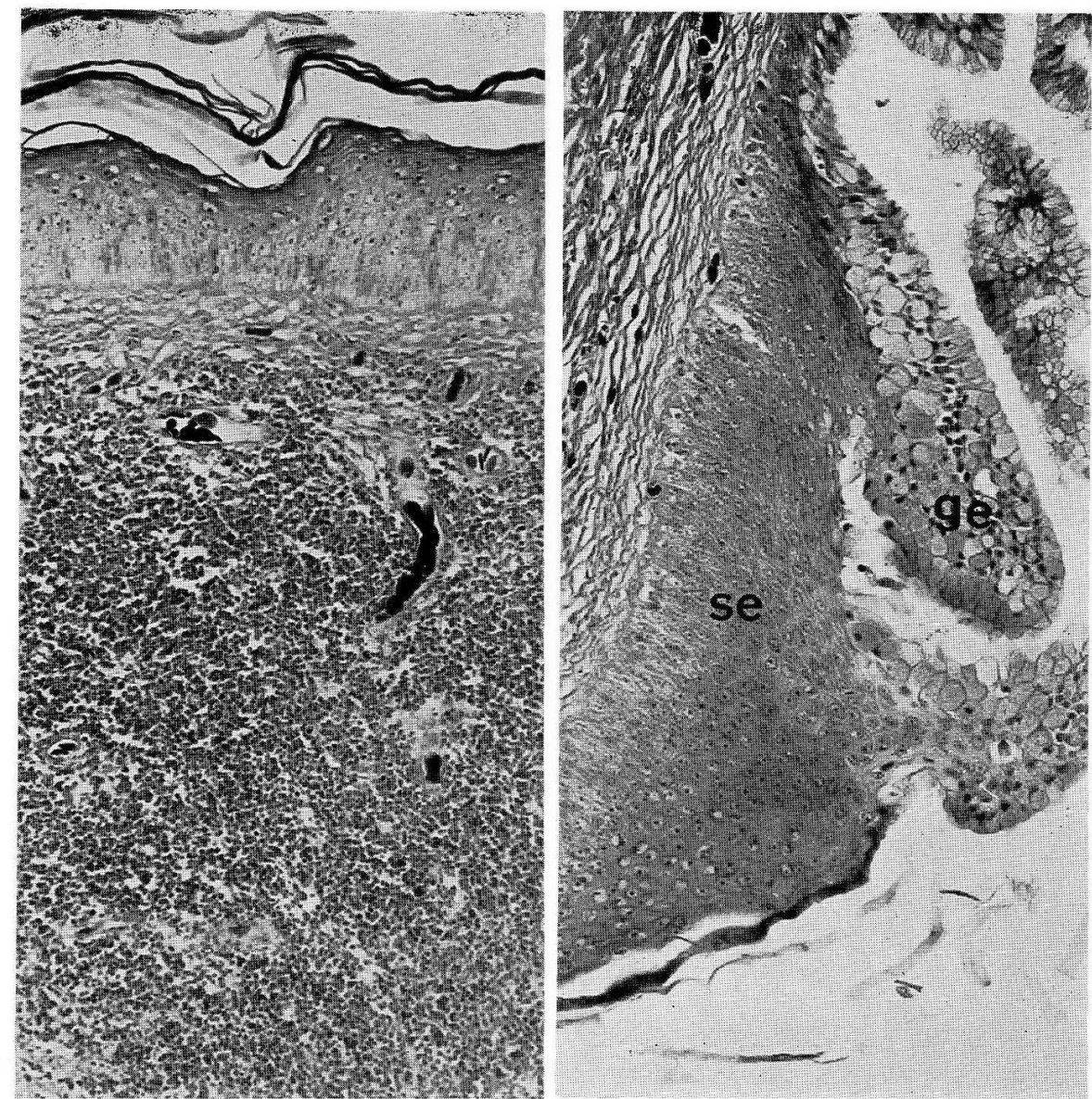

11

Fig. 10. In the distal part of the esophagus a great amount of lymphoid tissue is seen in the lamina propria. Azan triple stain. $\times 130$

Fig. 11. At the esophageal-cardiac junction, so-called gastric epithelium (ge) is present in addition to the stratified squamous epithelium (se). Azan triple stain. $\times 130$

corneum appeared to have regular stratification, and is stained intensely with acid dyes, such as eosin and azocarmine (Fig. 9).

The cornified layer wrapping the hard spine is considerably thick, attaining more than $100 \mu$ (Fig. 5), while the layer in other portions of the esophagus measure only 15 to $35 \mu$ (Fig. 6-10). At the basal part of the spine, it is evident that the lining epithelium includes the multiple layers of sloughing stratum corneum (Fig. 6, 8). However, at the cardia the cornified layer of the esophagus is replaced by the mucous epithelium of the stomach, although the stratified squamous epithelium still occurs in this region (Fig. 11). The boundary between the esophagus and stomach is not so clearly demarcated.

A central core of connective tissue extends from the lamina propria. It consists of collagen fibers and small vessels (Fig. 5). No secondary papillae are seen extending 
into the epithelium covering the spine. Neither are found connective tissue papillae beneath the proper mucosal epithelium. In the distal part of the esophagus, it is noticed that a large amount of diffuse lymphoid tissue is contained in the lamina propria (Fig. 10). No glandular tissue, such as esophageal gland and cardiac gland, is detectable to the entire esophageal region.

\section{Discussion}

The present examination revealed that the entire esophageal mucosa of the Pacific ridley turtle is lined by a stratified squamous epithelium which comprises three strata. It is interesting to know that the prominent structure of the esophageal spines are histologically the epithelium cored by the lamina propria. The remarkable hardness of the spine is due to the extremely thick keratinized layer.

With regard to dietary habits, in several mammalian species lacking toothed jaws like turtles and birds, some forms of compensation take place in the digestive system. For example, one of the systematically primitive mammals, the spiny anteater or echidna (Tachyglossus aculeatus) possesses a set of highly specialized keratinized spines on the base of the tongue. By occlusion with a similar set of spines on the palate, these lingual spines serve to masticate the food prior to swallowing (Doran and BAGGETT, 1972). In the scaly anteater, Chinese pangolin (Manis pentadactyla), the entire stomach is lined by a keratinized stratified squamous epithelium, and its pyloric mucosa is markedly thickened and equipped with numerous hard spines. The components of the spine are basically the five strata which are normally found in the thick skin of mammals (KRAUSE and LEESON, 1974a). On the other hand, the stomach of the echidna is lined by a stratified squamous epithelium which is not truly keratinized. Instead, however, of keratinized covering, near the pylorus of the echidna there are found projections whose epithelium is constructed of three strata as in the case of the present turtle (KRAUSE and LEESON, 1974b).

The scanning electron microscopy revealed that the esophageal spines of the present turtle are similar in surface structure to the pyloric spines of the pangolin, although the former are much larger, stouter and sharper than the latter (KRAUSE and LEESON, 1974a). Like those of the echidna, the spines of the turtle are composed of three strata lacking stratum granulosum and stratum lucidium which still remain in the case of the pangolin. However, the stratum corneum of the turtle is truly keratinized as was documented in the pangolin (KRAUSE and LeEson, 1974a, b).

Generally speaking, the oral cavity of the terrestrial vertebrates is covered by keratinized cells, while mucus-producing cells are seen in aquatic vertebrates including the turtle (MEYer and PrutKin, 1974). Using several species of larval amphibians, Altig (1973) surveyed scanning electron microscopically the keratinized structures occurring in the surface of toe tip, upper jaw, dental sheath and labial teeth. Essentially, the keratinized surface of all organs examined does not differ with different vertebrates.

As is well known, if five species are combined, the main foods of marine turtles found in Japanese waters are the algae, jelly fish, crustaceans, molluscs, salps and fishes. The results obtained in the stomach contents of the present Pacific ridley turtle lend support to the information mentioned above (HonMA and Yoshie, 1975). The turtle lacking toothed jaws apparently grinds food by means other than chewing. 
Therefore, it is natural to consider that the esophagus equipped with the sharp and hard spines in the turtle may contribute to break various kinds of foods into small pieces. Anyhow, more detailed, phylogenetic and ontogenetic studies are needed to elucidate the real biological significance of the esophageal spines of the marine turtle.

Acknowledgments. We express our thanks to Dr. S. Nagahama, Department of Oral Anatomy, Nippon Dental College, Tokyo, for his encouragement during the course of this work.

\section{ヒメウミガメの食道上皮突起に関する組織学的観察}

$$
\text { 吉 汇 紀夫と本間義 治 }
$$

熱帯産の雌ヒメウミガメ穵用い，特異的に発達した食道を光顕ならびに走査電顕により 観察した，食道恏，著しく角化した重層扁平上皮よりなり，その大部分注多数の突起（別 名 咽頭歯）となっている，食道上皮は 3 層すなわち胚芽層, 有棘層および角質層からな る，突起の表面は，鱗片状に涂離していく角化細胞によって扮抒われており，角質層が極

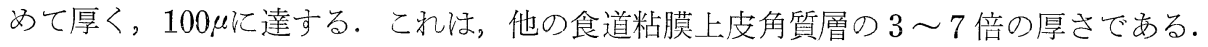

顎蒾定欠くウミガメにみられたこれら特異な形状の突起ほ，飲みこんだ食物を細片に くだくのに役立っているらしい.

\section{References}

Altig, R. : Preliminary scanning electron observations of keratinized structures of amphibian larvae. Hiss News-J. 1: 129-131 (1973).

Bellairs, A.: The life of reptiles. In (ed. by) R. Carrington: The Weidenfeld and Nicolson natural history. Vol. 1. Cleveland and New York, World Publishing Co., 1969.

Doran, G. A. and H. Baggett： The specialized lingual papillae of Tachyglossus aculeatus. I. Gross and light microscopic features. Anat. Rec. 172: 157-166 (1972).

Honma, Y. and S. Yoshie: A record of the Pacific ridley turtle, Lepidochelys olivacea, from the coast of Niigata facing the Japan Sea, with description of some of the organs. Ann. Rep. Sado Mar. Biol. Stat., Niigata Univ. 5: 1-9 (1975).

Krause, W. J. and C. R. Leeson: The stomach of the pangolin (Manis pentadactyla) with emphasis on the pyloric teeth. Acta anat. 88: 1-10 (1974a). J. Morphol. 142: 285-300 (1974b).

Meyer, V. and L. Prutkin: An ultrastructural study of the oral mucous membrane of the turtle, Pseudem ys scripta elegans. Acta anat. 89: 89-99 (1974).

\section{吉江 紀夫}

T951 新潟市浜浦町 1-8

日本歯科大学新潟歯学部

口腔解剖学教室

\section{Sumio Yoshie}

Department of Oral Anatomy

Nippon Dental College

Hamaura-cho 1-8,

Niigata, 951 Japan 